proposed. The second half, which after passage of Nicol 2 is totally reflected at $\mathrm{Nicol} I$ and then returned upon its course, on its arrival at Nicol 2 is not transmitted (as Wien seems to suppose) but is totally reflected. When again returned upon its course by a perpendicular reflector, and again rotated through $45^{\circ}$ by the magnetised medium, it is in a condition to be completely transmitted by Nicol I, and thus finds its way to body I, and not to body 2 as the argument requires. The two bodies receive altogether the same amount of radiation, and there is therefore no tendency to a change of temperature.

Although I have not been able to find any note of it, I feel assured that the above reasoning was present to my mind when I wrote the passage already cited.

RAYLEIGH.

\section{MARTIN F. WOODWARD}

I M Martin Fountain Woodward, whose untimely death by drowning we recorded in our issue of September 26 , science has lost an untiring devotee, zoology a brilliant student and investigator, a teacher whose personal influence and example will live in the memory of those to whom he so willingly imparted knowledge.

M. F. Woodward, younger son of Dr. H. Woodward, F.R.S., keeper of the geological department of the British Museum of Natural History, was born in London on November 5, I865, and educated at Kensington Grammar School. In 1883 he entered the Royal School of Mines and Normal School of Science as an associate student, qualifying in 1885 with distinction, as the recipient of the Murchison medal and prize of books, for excellence in geology. In zoology he attended the last session's work conducted by the late Prof. Huxley. In both elementary and advanced examinations he headed the passlist, and showed his power by an achievement in the practical work which so far excelled all precedent that for years his dissection was at Huxley's request kept for use, as an ideal to which the ordinary student might aspire. In this and his class-work combined, Woodward evinced such special aptitude for biological study that Huxley at once appointed him an assistant. In the following year he was made demonstrator of zoology, and in that capacity he continued to labour zealously and with great ability for the remaining seventeen years of his life, inspiring affection and respect in all with whom he came in contact.

With advancing years, Woodward developed a special aptitude for microchemical work and marine investigation. His fame as a prepa rateur brought to him numerous friends and coworkers anxious to benefit by his assistance and advice, who are to-day unanimous in their admiration of his manipulative skill and mental attainments. His mind was ever clear, his judgment sound, and by his energetic enthusiasm and foresight he was at times directly influential in uprooting error and misinterpretation in their work, thereby earning their lasting gratitude. $\mathrm{His}$ leaning towards marine zoology received a welcome impetus in an opportunity afforded him in the summer of 1887 , by Mr. W. H. Hudleston, F.R.S., of conducting a dredging trip in the English Channel, at the conclusion of which his efforts elicited the high encomium of his friend. He later spent his summer vacations in marine research, exploring the fauna of the Channel Islands, working at the Plymouth Marine Station, till finally, through the instrumentality of Mr. E. W. L. Holt, whose friendship he made while he was a student in our College, he was enabled to spend his last three vacations at the Marine Biological Laboratory of the Irish Fishery Board, first at Inishbofin and then at Moyard, where he met his death. Published reports bear testimony to the success of his achievements, and in a recent letter the VicePresident of the "Department of Agriculture and NO. I 667 , VOL. 64$]$
Technical Instruction for Ireland," under which the later work was done, has highly eulogised his labours, character, and attainments. Only a few days before his death, Woodward, in a letter to his friends, wrote with delight of a 380 -fathoms haul, which had yielded a Haloporphyrus, a large Pomatomus, and about 20 Asthenosomas, rare captures for the British Seas. In describing this catch he presented a word-picture worthy his high artistic ability, which, while testifying to his own great enthusiasm, appealed strongly to that of the zoologists to whom it was communicated.

Woodward from time to time published papers on subjects of special study, the outcome of work done in the scanty leisure his official duties allowed. Among the earlier of these is a valuable paper in the Proc. Zool. Soc. for 1892 on the dentition of Hyrax, Huxleyean in its methods and based on the specimens briefly recorded by Huxley in 1863 . In this memoir much that was hitherto confusing in the dentition both of Hyrax and other placentalia was rendered clear, and through it Woodward was led to an extended inquiry into the genesis and succession of the teeth in the marsupialia, with the result that his published memoirs placed him in the front rank of comparative odontologists. To have revolutionised our conceptions of the incisors of the Diprotodonts, to have shown that the single so-called successional cheek-tooth of the marsupialia is most probably a retarded pre-molar, and to have contributed to the unravelling of the intricacies of the tooth-complex of the Insectivora, is to have essayed a plucky task and to have earned the lasting gratitude of zoologists of all nationalities.

Woodward, true to his family traditions, cultivated a love of the Mollusca, and upon these animals he published a series of most valuable papers, terminating in a well-nigh exhaustive study of the famous Pleurotomaria, published in the Qu. Jour. Microscp. Sci. for 1891 . His papers upon other molluscs were for the greater part contributed to the Proceedings of the Malacological Society, of which he was one of the original members and the secretary at the time of his death. To read these memoirs is to appreciate the fact that Woodward possessed a knowledge of molluscan morphology second to that of no living malacotomist, and his discussion of the affinities of the Monotocardia set forth in his last published paper may be recommended to those who would gauge his reasoning capacity. Upon the Mollusca he had long specialised, and his concluding act as a teacher was a course of lectures at the Royal College of Science which for depth and originality of treatment will be a lasting memorial to his powers to those who were so fortunate as to hear them. They embodied his preliminary notes and ideas for a book he had intended to write, and it is terrible to think that with his death this brilliant achievement has been cut short.

Ever alert for a new observation, Woodward, as opportunity occurred, made public his passing notes. As an example may be cited his intensely interesting discovery of an earthworm possessed of seven pairs of ovaries. He performed a notable task, involving the spare time of three of his best years, in editing the English edition of vols. ii., iii. and iv. of Korschelt and Heider's " Text-book of Embryology," the emendations, curtailments, and annotations which he effected materially increasing the value of the work.

Woodward was always ready to cooperate with friends and fellow workers in anything which would advance our knowledge of the phenomena of life. He leaves behind him a magnificent series of photomicrographs of the fertilisation process in Ascaris megalocephala, made from sections which he had prepared, and an extensive series of preparations, drawings, and notes, upon the spermatogenesis of the Mollusca, the rough arrangement of which constituted the closing act of his College life. 
On August 2, Woodward, having just recovered from a surgical operation, journeyed to Moyard, in company with his friend Mr. W. Watson, F.R.S., assistant professor of physics in the Royal College of Science, who had before accompanied him on similar occasions. On Sunday, September 15 , after spending the day with their friend Mr. Allies, resident land-owner of Inishbofin and other adjacent islands of the Galway seaboard, on the return journey and within sight of land their boat was capsized by a sudden squall. While Watson and the fisherman in charge managed with extreme difficulty to reach the shore, Woodward, though a good swimmer, sank and entirely disappeared, and although every effort was made to recover the body, it was not brought to the surface till September 27.

He was laid to rest on Sunday, September 29, in the peaceful little Protestant churchyard at Moyard, in the presence of his two sisters, Mr. Watson, Mr. Holt, of the Irish Fisheries Board, and a few of his devoted friends. One reflects with sorrow that circumstances should have combined to remove from the world of action before he was thirty-six a man so universally esteemed. We revere his memory as that of an earnest and original worker, loving and sympathetic, whose self-sacrificing nobility of character, critical capacity, and devotion to the cause of science will long be remembered by the many friends who mourn his loss.

G. B. H.

\section{NOTES}

The Harveian Oration of the Royal College of Physicians will be delivered by Dr. Norman Moore on Friday, October 18.

WE regret to have to record the death, at the age of sixtynine, of M. R. Koenig, of Paris, well-known for his researches in acoustics, light and heat.

THE Journal of Botany records the death, from cholera, in India, on September I4, of a promising young botanist, Mr. William West, at the age of twenty-six. Mr. West had passed a distinguished career at the Royal College of Science, where he obtained the Forbes medal for botany, and at Cambridge, though greatly marred by ill health. He had devoted himself chiefly to the study of freshwater algæ, and had gone to India as biologist to an Indigo Planters' Association.

THE ship Discovery, engaged on the British exploring ex. pedition in the Antarctic regions, arrived at Cape Town on October 3. After coaling the Discovery will proceed to Simons Bay and thence direct to Lyttelton, not calling at Melbourne in order to save time.

SPEAKING at Upsala to the Swedish Geographical Society on Wednesday of last week, Prof. Nordenskjöld announced that the Swedish South Polar Expedition would be ready to start soon after the 8 th inst. After reaching the Falkland Islands, where a depôt will be established, the expedition will continue its voyage southwards. After making their way as far south as possible, the explorers will look for a spot suitable for wintering in. The ship, with three geologists on board, will then return to the Falkland Islands, whence scientific excursions will be conducted throughout the winter. The expedition will probably return to Sweden at the beginning of 1903 .

IT is announced in the German semi-official newspapers that the German Government has again placed at the disposal of the Chinese Government the astronomical instruments which were removed from Peking by the German contingent. The Chinese Government has replied that in view of the inconvenience and difficulties which would be involved in conveying the instruments back to China and placing them in their former position it declines the offer.

$$
\text { NO. I } 667 \text {, VOL. 64] }
$$

THE resignation of Dr. Purser, King's Professor of the Institutes of Medicine in the School of Physic, Trinity College, Dublin, is announced. In I899, on the completion of the twenty-fifth year of his professorship, Dr. Purser's past pupils, in token of their appreciation of him and his services, founded the "John Mallet Purser Medal" for award yearly in the School of Physic to the candidate who obtains the highest marks in physiology and histology at the Half M.B. examination. Prof. Purser's decision has been arrived at, not on account of illhealth or failing energy, but, as the British Medical Journal understands, in order that with the increased laboratory accommodation which the Board of Trinity College has provided for the teaching of physiology and histology his successor may have the advantage of equipping the laboratory and organising the work on the more extended basis.

A Reuter telegram, dated October 7 , gives further particulars as to the progress of the campaign in Freetown, Sierra Leone, of the Liverpool School of Tropical Medicine against mosquitoes. Up to September 17, 6500 houses had been cleared by Dr. Logan Taylor and his assistants of the receptacles in which the Culex mosquitoes breed, and draining operations against the Anopheles mosquitoes are being pushed forward as much as the rain will allow. In addition to fifty other men employed on the operations of the expedition, two men are specially employed to look constantly after the centre of the town, where the offices, warehouses, and European houses are. The Governor, Sir Charles King Harman, is giving every assistance. Dr. C. W. Daniels, medical superintendent of the London School of Tropical Medicine, who was attached to the expedition and has been studying Dr. Taylor's work at Free. town, has now returned to England. In a report of his observations, addressed to Major Ross, he says :-" In my opinion your efforts have aiready been crowned with a large degree of success, as there has been a noteworthy diminution in the number of the two first genera of mosquitoes, Anopheles and a kind of Culex, found in the houses. The number o oreeding ground has been enormously diminished."

AT the International Congress of Physiologists recently held at Turin a noteworthy tribute of esteem was paid to Sir Michael Foster on his resigning the presidency to his successor, Prof. Angelo Mosso. This consisted in the presentation of a plaque, of which we reproduce (from the British Medical Journal) the inscription, granting him the unique distinction of Honorary Perpetual President of the Congress. The wording on the plaque is as follows :-

CONVENTUS PHYSIOLOGORUM INTERNATIONALIS QUINTUS HOC DIE VIRUM ILLUSTRISSIMUM SENIOREM

M I C H A E L E M F OSTER PRAESIDEM HONORARIUM PERPETUUM CONVENTUUM PHYSIOLOGICORUM INTERNATIONALIUM CREAVIT

$$
\begin{aligned}
& \text { CONVENTUS NOSTRI GRAVISSIMI VIRI DOCTI AUCTORITA } \\
& \text { TE EIUSDEMQUE STUDIO STRENUO INTEGRE FLORENT } \\
& \text { FOSTERO CATALOGU SCIENTIARUM NATURALIUM QUO } \\
& \text { NEMO IAM NATURAE INDAGATOR CARERE POTEST } \\
& \text { DEBEMUS GRATIA SIT HONOSQUE PROPUGNATORI } \\
& \text { NOSTRO! NOMINE CONVNTUUM PHYSTOLGICORUM } \\
& \text { INTERNATIONALIUM CONVETUS QUINTI PRAESES } \\
& \text { ANGELUS MOSSO. } \\
& \text { AUGUSTAE TAURINORUM AD XV KAL. OCT. A. MCMI. }
\end{aligned}
$$

THE Hanbury gold medal for 1901 was presented on the Ist inst. to Dr. George Watt by the president of the Pharmaceutical Society. This medal, which was established as a memorial to Daniel Hanbury, is awarded biennially for high excellence in the prosecution or promotion of original research in the chemistry and natural history of drugs, and the council of the Pharmaceutical Society are the trustees of the memorial fund. 